\title{
Phenotypic Heterogeneity in a Congenital Disorder of Glycosylation Caused by Mutations in STT3A
}

DOI:

$10.1177 / 0883073817696816$

\section{Document Version}

Accepted author manuscript

Link to publication record in Manchester Research Explorer

\section{Citation for published version (APA):}

Ghosh, A., Urquhart, J., Daly, S., Ferguson, A. P., Scotcher, D., Morris, A. AM., \& Clayton-Smith, J. (2017). Phenotypic Heterogeneity in a Congenital Disorder of Glycosylation Caused by Mutations in STT3A. Journal of child neurology, 32(6), 560-565. https://doi.org/10.1177/0883073817696816

\section{Published in:}

Journal of child neurology

\section{Citing this paper}

Please note that where the full-text provided on Manchester Research Explorer is the Author Accepted Manuscript or Proof version this may differ from the final Published version. If citing, it is advised that you check and use the publisher's definitive version.

\section{General rights}

Copyright and moral rights for the publications made accessible in the Research Explorer are retained by the authors and/or other copyright owners and it is a condition of accessing publications that users recognise and abide by the legal requirements associated with these rights.

\section{Takedown policy}

If you believe that this document breaches copyright please refer to the University of Manchester's Takedown Procedures [http://man.ac.uk/04Y6Bo] or contact uml.scholarlycommunications@manchester.ac.uk providing relevant details, so we can investigate your claim.

\section{OPEN ACCESS}


Phenotypic heterogeneity in a congenital disorder of glycosylation caused by mutations in STT3A

\begin{tabular}{|l|l|c|l|}
\hline Author & Highest degree & Affiliation & Email \\
\hline Arunabha Ghosh & MSc MRCPCH & 1,5 & arunabha.ghosh@cmft.nhs.uk \\
\hline Jill Urquhart & PhD & 2 & Jill.Urquhart@cmft.nhs.uk \\
\hline Sarah Daly & PhD & 2 & sarddaly@gmail.com \\
\hline Anne Ferguson & MBChB, MRCP, & 3 & anne.ferguson@cmft.nhs.uk \\
& FRCPCH, DCCH & & Diana.Scotcher@cmft.nhs.uk \\
\hline Diana Scotcher & MSc & 2 & Andrew.Morris@cmft.nhs.uk \\
\hline Andrew AM Morris & PhD FRCPCH & 1 & Jill.Clayton-smith@cmft.nhs.uk \\
\hline Jill Clayton-Smith & MD FRCP & 2,4 &
\end{tabular}

\section{Affiliation list}

\begin{tabular}{|c|l|}
\hline $\mathbf{1}$ & $\begin{array}{l}\text { Willink Biochemical Genetics Unit, Manchester Centre For Genomic Medicine, Central } \\
\text { Manchester University Hospitals NHS Foundation Trust, Manchester Academic Health } \\
\text { Science Centre, Manchester, UK }\end{array}$ \\
\hline $\mathbf{2}$ & $\begin{array}{l}\text { Manchester Centre For Genomic Medicine, Central Manchester University Hospitals } \\
\text { NHS Foundation Trust, Manchester Academic Health Science Centre, Manchester, UK }\end{array}$ \\
\hline $\mathbf{3}$ & $\begin{array}{l}\text { Community Paediatrics, Central Manchester University Hospitals NHS Foundation } \\
\text { Trust, Manchester, UK }\end{array}$ \\
\hline $\mathbf{4}$ & $\begin{array}{l}\text { Institute of Evolution, Systems and Genomics, Faculty of Medical and Human Sciences, } \\
\text { University of Manchester, UK }\end{array}$ \\
\hline $\mathbf{5}$ & $\begin{array}{l}\text { School of Biological Sciences, Faculty of Biology, Medicine and Health, University of } \\
\text { Manchester, UK }\end{array}$ \\
\hline
\end{tabular}

\section{Corresponding author:}

Dr Andrew AM Morris

Willink Biochemical Genetics Unit

Manchester Centre For Genomic Medicine

$6^{\text {th }}$ Floor, St Mary's Hospital

Manchester, UK

M13 9WL

andrew.morris@cmft.nhs.uk

Tel: $01617012137 / 8$

Fax: 01617012303

Word count: 2902

Tables: 1

Figures: 2 


\section{ABSTRACT}

STT3A encodes the catalytic subunit of the oligosaccharyltransferase complex. A congenital disorder of glycosylation (CDG) caused by mutations in STT3A has only been reported in one family to date, associated with a Type I CDG pattern of transferrin glycoforms. We describe a further five related individuals with a likely pathogenic variant in STT3A, two of whom also had variants in TUSC3. Common phenotypic features in all symptomatic individuals include developmental delay, intellectual disability, with absent speech and seizures. Two individuals also developed episodic hypothermia and altered consciousness. The family were investigated by autozygosity mapping, which revealed both a homozygous region containing STT3A and, in addition, a homozygous deletion of TUSC3 in one child. A likely pathogenic variant in STT3A was confirmed on Sanger sequencing of all affected individuals: we discuss the molecular findings in detail and further delineate the clinical phenotype of this rare disorder.

\section{INTRODUCTION}

Congenital disorders of glycosylation (CDGs) are a rapidly growing group of disorders resulting in defects in the synthesis of the $\mathrm{N}$ - or O- glycan moiety of glycoproteins, or their attachment to polypeptide chains of proteins.

The $\mathrm{N}$-glycosylation takes place in the cytoplasm, endoplasmic reticulum and Golgi apparatus, and proceeds in four stages: synthesis of lipid-linked oligosaccharide, transfer of the carbohydrate chain from dolichol phosphate to the nascent polypeptide chain of protein, remodelling of the $\mathrm{N}$-glycan chain in the endoplasmic reticulum, and further modification of the $\mathrm{N}$-glycan chain in the Golgi. ${ }^{1}$

The oligosaccharyltransferase complex is involved in the transfer of glycan chains to proteins in the endoplasmic reticulum. Oligosaccharyltransferase is composed of seven or eight subunits, of which mutations in four (TUSC3, MAGT1, DDOST, STT3) have been reported to cause CDGs, though only two (DDOST, STT3) are associated with abnormal glycosylation of transferrin. ${ }^{2}$ The STT3 subunit is the catalytic subunit of oligosaccharyltransferase. 
In mammalian cells, two distinct isoforms of the oligosaccharyltransferase complex are expressed, consisting of either the STT3A or STT3B subunits and shared accessory subunits ${ }^{3}$. The two alternate proteins have partially overlapping functions: STT3A mediates co-translational glycosylation of nascent polypeptide chains, while STT3B is responsible for post-translational glycosylation of acceptor sites that have skipped glycosylation by the STT3A complex. ${ }^{4,5}$

CDG caused by mutations in STT3A, termed STT3A-CDG in current nomenclature, has to date been reported in only one family of Pakistani origin where two affected siblings presented with microcephaly, developmental delay, failure to thrive, seizures and hypotonia. ${ }^{2}$ The more severely affected brother also had problems with visual tracking and was reported to have cerebellar atrophy. The parents were consanguineous. A homozygous mutation c.1877C > T was identified in STT3A in this patient. The authors also described another individual in the same report with CDG caused by mutations in STT3B.

Here we describe five individuals with CDG caused by the identical variant in STT3A, two of whom coincidentally also carry a deletion of TUSC3, a gene encoding another subunit of oligosaccharyltransferase. Written informed consent was obtained from the families of all individuals for being included in the study.

\section{FAMILY HISTORY}

The pedigree of the family is shown in Figure 1. We investigated two male siblings (Patients IV-1 and IV-2) from a multiply consanguineous family of Pakistani origin because of developmental delay and feeding problems. The sister of the two boys (IV-3) has much less severe developmental delay but significant microcephaly (occipitofrontal circumference $<0.4^{\text {th }}$ centile). The youngest sibling (IV-4) was investigated at birth due to the diagnosis being known in his brothers. At one month of age he is so far asymptomatic with no abnormal neurological findings or microcephaly (occipitofrontal circumference 
on $25^{\text {th }}$ centile). The father of these four children had two siblings who died at an early age and were said to have problems similar to the eldest child. The mother has two brothers with severe learning difficulties, one of whom has epilepsy. They were not available for examination. Three maternal cousins (Patients III-7, III-8 and III-9) also presented with severe developmental delay, absent speech and seizures. Two of the three had microcephaly.

\section{CLINICAL REPORTS}

The eldest sibling from Family 1, (Patient IV-1) was born at full term by Caesarean section due to breech presentation. Birth weight was $2.79 \mathrm{~kg}\left(9^{\text {th }}\right.$ centile) and birth occipitofrontal circumference was $32 \mathrm{~cm} \mathrm{(2}{ }^{\text {nd }}$ centile). There were parental concerns about abnormal visual behavior by 4-6 weeks of age, and severe vomiting from 8 weeks. He presented to his local paediatrician at 11 weeks of age, by which time global developmental delay was apparent. He had significant head lag, truncal hypotonia, no social smile, severe visual impairment with roving eye movements and optic atrophy on fundoscopy. Newborn hearing screening assessments were satisfactory but subsequently there were concerns about hearing impairment; though parents felt that he was able to respond to voices of family members, no definite responses to sounds were observed in clinic. There were no dysmorphic features but he was severely microcephalic (below 0.4 th centile). No abnormality was seen on brain CT performed at 4 months of age. By 5 months of age he had developed seizures, predominantly myoclonic jerks but with occasional generalised tonic-clonic seizures. At this stage, EEG (electroencephalogram) showed epileptiform activity in both temporal regions, predominantly over the right temporal region but occasionally in a more generalised distribution. By two years, the EEG showed a more generalised burst suppression pattern. Seizures were extremely difficult to control despite therapy with leviteracetam and phenobarbital. He continued to have two to three clusters of myoclonic jerks daily, often following waking. By six months of age he had developed spasticity of the lower limbs and this pattern of motor disability persisted. He has never been able to sit without support. Vomiting continued to be a major problem and he required complete gastro-oesophageal dissociation at 18 months and gastrostomy feeding. Oral secretions were problematic and were 
managed with hyoscine patches and glycopyrronium. There was no evidence of liver involvement and liver function tests were consistently normal.

From four years of age he developed episodes of reduced consciousness and hypothermia. At these times he appeared to be very deeply asleep and not rousable, with reduced respiratory rate and temperature dropping to $34-35^{\circ} \mathrm{C}$ (Figure 2). These episodes could last for up to 2 days, during which time urine output was decreased. A cluster of seizures often followed waking from these episodes. Plasma thyroid stimulating hormone and free thyroxine were normal. He developed osteopenia and recurrent fractures. At 11 years of age he remains non-ambulatory, requiring a customized wheelchair and gastrostomy feeding, with occasional myoclonic jerks and temperature variability. Currently his weight is $40 \mathrm{~kg}\left(75^{\text {th }}\right.$ centile), height is on the $25^{\text {th }}$ centile and occipitofrontal circumference is $49.1 \mathrm{~cm}$ (well below the $0.4^{\text {th }}$ centile).

The younger brother of IV-1, IV-2 was born at full term by elective Caesarean section with a birth weight of $2.26 \mathrm{~kg}\left(<0.4^{\text {th }}\right.$ centile). Delayed gross and fine motor development was apparent by 8 months. In contrast to his brother, there were no concerns regarding visual development or hearing, and there was no microcephaly, his occipitofrontal circumference being $41.5 \mathrm{~cm}\left(25^{\text {th }}\right.$ centile) at the age of 5 months. At 15 months of age, he had a series of generalised tonic-clonic convulsions and was commenced on sodium valproate. Sleep deprived EEG demonstrated frequent bursts of spike and wave in a generalised pattern, consistent with generalised epilepsy. Though he did not have further generalised tonic-clonic convulsions, he continued to have frequent seizures of multiple types, including eye rolling, myoclonic jerks of the right arm and leg during sleep, and arm stiffening. These were treated with sodium valproate and lamotrigine, though he continued to have around two clusters of seizures per day. Feeding was difficult, necessitating gastrostomy insertion at the age of 2 years. At 3 years he had several episodes of mild hypoglycaemia with inappropriately raised insulin levels. He was commenced on diazoxide, though this was discontinued after one year and monitoring of glucose levels was satisfactory. At 4 years he developed 
recurrent epistaxis and was found to have mildly abnormal coagulation, with a slightly prolonged prothrombin time (12.6 seconds) and normal activated partial thromboplastin time. The episodic epistaxis resolved spontaneously and no further intervention was considered necessary. Liver transaminases were normal.

From four years of age he began to have episodes of deep sleep, particularly after feeds, with the associated symptoms, such as cold extremities, also seen in his brother. These episodes occurred at any time of day and he would be unrousable for 3-4 hours. A 24-hour EEG showed no epileptiform activity. Thyroid function tests were normal. He continues to have infrequent seizures and episodes of deep sleep at 6 years of age. He has made some developmental progress and is able to reach a sitting position without support, though development remains globally delayed. Currently his weight is $24.5 \mathrm{~kg}$ $\left(>75^{\text {th }}\right.$ centile), height is $112 \mathrm{~cm}$ ( $9^{\text {th }}$ centile) and occipitofrontal circumference lies between $0.4^{\text {th }}$ and $2^{\text {nd }}$ centiles.

The third affected individual, III-7, is a first cousin of the mother of individuals IV-1 and IV-2. She was born at full term by normal delivery following an uncomplicated pregnancy. Birth weight was $2.5 \mathrm{~kg}$ ( $2^{\text {nd }}$ centile $)$.

Developmental delay was apparent by 5 months of age. She developed generalised tonic-clonic seizures at 10 months of age and her EEG showed widespread bursts of bilateral sharp wave activity, consistent with generalised epilepsy. Seizures were controlled by sodium valproate. There were no concerns about hearing or visual impairment and she was not dysmorphic. Urine amino and organic acids and mucopolysaccharides, thyroid and liver function and a lysosomal enzyme screen were normal, as was CT brain at the age of five years. By 10 years of age she was making very slow developmental progress, still unable to walk, with increased muscle tone and limb contractures. She was also noted to have unusual stereotypic movements including some hand-wringing, rocking and head-banging. By 17 years of age she was losing weight due to very poor appetite and required gastrostomy insertion. She has never achieved independent ambulation but was able to walk with assistance and she had developed sleep disturbance. 
When last reviewed at 25 years, she had developed spasticity in the limbs and a kyphotic posture. She was less mobile and had a very poor sleep pattern and challenging behaviour. She is microcephalic with occipitofrontal circumference below the $0.4^{\text {th }}$ centile.

The younger sister of III-7, III-8 was born at term and developed seizures at the age of four days associated with hypocalcaemia, thought to be secondary to maternal vitamin D deficiency. She went on to have severe developmental delay and persisting seizures, with a normal CT brain scan and normal routine investigations including liver function tests. By 5 years she was noted to have rocking movements similar to her sister. She also startled very easily. Her seizures were initially controlled with sodium valproate and lamotrigine but by the age of 15 years, she was able to stop anticonvulsants. There were no concerns about her hearing or vision and she has good comprehension but no expressive language. She began to walk with support at three years of age but had truncal ataxia and an unsteady gait. By age 3 years, she had limb hypertonia and walked with flexion at the hips. At age 20 years, she remains able to walk and does not have feeding problems but, like her sister, has developed sleep disturbance. She is overweight and has developed some dark pigmentation on her skin, considered to be acanthosis nigricans. Height is $149 \mathrm{~cm}\left(2^{\text {nd }}\right.$ centile), weight $72 \mathrm{~kg}\left(>91^{\text {st }}\right.$ centile) and occipitofrontal circumference lies on the $10^{\text {th }}$ centile.

The youngest sister, III-9 was born at term following an uncomplicated pregnancy. Her birth weight was $3.15 \mathrm{~kg}\left(25^{\text {th }}\right.$ centile $)$ and her initial head size lay on the $10^{\text {th }}$ centile. She developed seizures at 9 months of age, when she was also noted to have delayed gross and fine motor development, extensor hypertonia of the trunk and lower limbs and flexor hypertonia of the upper limbs. She developed body rocking movements similar to her sisters. She was not dysmorphic. A CT brain scan was normal. From 18 months of age, she has had severe problems with self-injurious behaviour. Seizures were managed with carbamazepine, later changed to valproate.

Developmental progress was slow and though she is able to walk, at 17 years of age she is still dependent on her carers for all aspects of self-care, 
including feeding, dressing and bathing. Her weight lies on the $25^{\text {th }}$ centile but she is now microcephalic with an occipitofrontal circumference of $50.7 \mathrm{~cm}$ $\left(<0.4^{\text {th }}\right.$ centile $)$.

The clinical features of all affected individuals are summarized in Table 1 and compared to the patient previously reported in the literature.

\section{FURTHER INVESTIGATIONS}

A glycosylation disorder was suspected in the affected family members and iso-electric focussing of serum transferrin was carried out on IV-1, IV-2, III-7 and III-9 according to standard methods. ${ }^{6}$ A satisfactory blood sample could not be obtained from III-8.

In view of the suspicion of an autosomal recessive disorder in the family, autozygosity studies were undertaken on the three affected siblings III-7, III-8 and III-9. Genome-Wide SNP microarray analysis using the Affymetrix Genome-Wide SNP6.0 microarray was carried out for the three affected siblings and genotypes were generated using the Birdseed v2 algorithm with a confidence threshold of 0.01 within the Affymetrix Genotyping console. Autozygosity analysis was carried out using AutoSNPa (http:// dna.leeds.ac.uk/autosnpa/) ${ }^{7}$ to determine regions of autozygosity $>2 \mathrm{Mb}$. Copy number data was generated using the SNP $6.0 \mathrm{CN} / \mathrm{LOH}$ Algorithm within the Affymetrix Genotyping console v4.2 and visualised using Chromosome Analysis suite v2.1. All co-ordinates given are based on hg19. Candidate regions of interest were reviewed for potential disease-causing genes and STT3A was identified as one of these. Sanger sequencing of STT3A was subsequently undertaken in the affected individuals.

\section{RESULTS}

In IV-1 initial results of transferrin isoelectric focussing were abnormal, but without a typical Type I or II CDG pattern. Repeat analysis at 18 months showed an abnormal pattern of transferrin glycoforms consistent with Type I CDG. Phosphomannomutase and phosphomannose isomerase enzyme activities were normal. In IV-2, analysis of transferrin glycoforms in the early neonatal period was normal, but repeat analysis at 1 month of age 
demonstrated a Type I CDG pattern. Phosphomannomutase and phosphomannose isomerase enzyme activities were normal. In III-7, transferrin isoelectric focussing performed at 10 years of age was normal. Transferrin glycoforms in case III-9 showed a Type I CDG pattern. It has not been possible to obtain a sample for testing from III-8.

On Sanger sequencing of STT3A, all five affected individuals, as well as the currently asymptomatic individual (IV-4), were found to have a homozygous change in STT3A c.1877T>C, p.(Val626Ala). This is the same variant as that reported in the family studied by Shrimal et al.

Analysis of the SNP array results undertaken for autozygosity studies revealed that IV-1 carried a $464 \mathrm{~KB}$ homozygous deletion of 8p22, with coordinates $8:(15,498,361-15,842,386)$. This results in partial nullisomy of the TUSC3 gene. This may explain the severity of his overall phenotype. This same deletion was carried in the heterozygous state only in IV-2, but in the homozygous state in the sister IV-3, explaining her phenotype of milder developmental delay and microcephaly. The deletion was not found in the currently asymptomatic individual IV-4.

\section{DISCUSSION}

This is the second reported family with STT3A-CDG. The individuals described here share a number of clinical features with the only previously published report of an individual with STT3A-CDG ${ }^{2}$ (Table 1) but have, in addition, other distinctive phenotypic features. In family 1 , both affected males have prolonged episodes of altered consciousness and hypothermia. Perinatal hypothermia is a recognised feature of a number of inborn errors of metabolism (organic acidaemias, Menkes disease, pyruvate carboxylase deficiency) and lethargy and hypothermia shortly after birth has been reported in PMM2-CDG. ${ }^{8}$ However, episodic lethargy and hypothermia in older children has not been reported as a feature of CDG. These episodes suggest hypothalamic dysfunction with a disturbance of central thermoregulation, though spontaneous episodes of hypothermia with somnolence has been described in otherwise well children without evidence of hypothalamic 
dysfunction. ${ }^{9}$ Hyperinsulinaemia has been postulated as the mechanism for spontaneous hypothermia in one case report ${ }^{10}$ and patient IV-2 initially had evidence of hyperinsulinism but this had resolved before the onset of episodes of lethargy and hypothermia.

The three affected sisters all had stereotypic hand movements, raising the possibility of Rett syndrome. Later, repetitive rocking movements developed. They had a disordered sleep pattern and challenging and self-injurious behaviour, which became the major management problem. Not all of the affected individuals in this reported family were microcephalic, demonstrating that this is not a universal feature of the condition.

The clinical picture in the elder sibling from Family 1 is likely to have been influenced by the fact that he also carries a homozygous deletion encompassing part of the TUSC3 gene at $8 \mathrm{p} 22$. This could explain why his phenotype has been so severe compared to the other affected individuals with the STT3A defect. Abnormalities of TUSC3 have been reported as a cause of autosomal recessive non-syndromic intellectual disability, ${ }^{11}$ the phenotype seen in IV-3, the sister of the affected boys. Unlike the STT3A defect, loss of function of TUSC3 does not result in hypoglycosylation of transferrin and it is hypothesised that the role of this subunit may be to ensure the glycosylation of a subset of proteins required for normal brain development. ${ }^{12}$ The episodes of periodic lethargy and hypothermia are unlikely to be primarily due to the TUSC 3 defect as they were observed in IV-2 who carries the deletion in the heterozygous state only, but not observed in the sister IV-3 who carries a homozygous deletion or in any previously reported patients. The occurrence of two different glycosylation disorders in the same family is coincidental but serves to remind us of the increasing number of glycosylation disorders now known to contribute to intellectual disability. Though to our knowledge, two glycosylation disorders within the same family has not been reported previously, many children with developmental disorders have composite phenotypes resulting from mutations in two or more genes ${ }^{13}$. 
In summary, we report five individuals with STT3A-CDG to help delineate the phenotype. We highlight periodic lethargy and hypothermia, stereotypic behaviours and sleep disorder as possible distinctive features which might alert one to the diagnosis, especially in families of Pakistani origin. The STT3A variant identified in this family, c.1877C $>$ T is identical to that described in the first family by Shrimal et al. and may be a founder mutation in the Pakistani population. 


\section{TABLES}

Table 1: Clinical features of reported individuals with STT3A-CDG

\begin{tabular}{|c|c|c|c|c|c|c|}
\hline 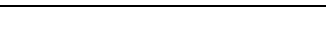 & IV-1 & IV-2 & III-7 & III-8 & III-9 & Shrimal et al \\
\hline \multicolumn{7}{|l|}{ Genotype } \\
\hline (STT3A) & $\begin{array}{l}\text { c. } 1877 \mathrm{~T}>\mathrm{C} \text {, } \\
\text { homozygous }\end{array}$ & $\begin{array}{l}\text { c. } 1877 \mathrm{~T}>\mathrm{C} \text {, } \\
\text { homozygous }\end{array}$ & $\begin{array}{l}\text { c. } 1877 \mathrm{~T}>\mathrm{C} \text {, } \\
\text { homozygous }\end{array}$ & $\begin{array}{l}\text { c. } 1877 T>C \text {, } \\
\text { homozygous }\end{array}$ & $\begin{array}{l}\text { c. } 1877 T>C \text {, } \\
\text { homozygous }\end{array}$ & $\begin{array}{l}\text { c. } 1877 \mathrm{~T}>\mathrm{C} \text {, } \\
\text { homozygous }\end{array}$ \\
\hline (TUSC3) & $\begin{array}{l}464 \text { kb deletion, } \\
\text { homozygous }\end{array}$ & $\begin{array}{l}464 \text { kb deletion, } \\
\text { heterozygous }\end{array}$ & No variants & No variants & No variants & - \\
\hline Age & 11 years & 6 years & 28 years & 20 years & 17 years & 13 years \\
\hline Microcephaly & Yes & No & Yes & No & Yes & Yes \\
\hline $\begin{array}{l}\text { Developmental } \\
\text { delay }\end{array}$ & Yes & Yes & Yes & Yes & Yes & Yes \\
\hline $\begin{array}{l}\text { Intellectual } \\
\text { disability }\end{array}$ & Yes & Yes & Yes & Yes & Yes & Yes \\
\hline $\begin{array}{l}\text { Cerebellar } \\
\text { atrophy }\end{array}$ & No & No & - & - & - & Yes \\
\hline Seizures & Yes & Yes & Yes & Yes & Yes & Yes \\
\hline $\begin{array}{l}\text { Abnormal visual } \\
\text { development }\end{array}$ & Yes & No & No & No & No & Yes \\
\hline Visual tracking & - & - & - & - & - & Yes \\
\hline Optic atrophy & Yes & Yes & - & - & - & No \\
\hline Hypotonia & Yes & Yes & No & No & No & Yes \\
\hline $\begin{array}{l}\text { Self-injurious } \\
\text { behaviour }\end{array}$ & No & No & No & No & Yes & - \\
\hline
\end{tabular}




\begin{tabular}{|c|c|c|c|c|c|c|}
\hline $\begin{array}{l}\text { Sleep } \\
\text { disturbance }\end{array}$ & No & No & Yes & Yes & No & - \\
\hline $\begin{array}{l}\text { Stereotypic } \\
\text { behaviours }\end{array}$ & No & No & Yes & Yes & Yes & - \\
\hline $\begin{array}{l}\text { Episodic } \\
\text { hypothermia and } \\
\text { reduced } \\
\text { consciousness }\end{array}$ & Yes & Yes & No & No & No & No \\
\hline Failure to thrive & Yes & No & No & No & No & Yes \\
\hline $\begin{array}{l}\text { Feeding } \\
\text { problems }\end{array}$ & Yes & Yes & Yes & No & No & Yes \\
\hline $\begin{array}{l}\text { Gl symptoms / } \\
\text { gastrostomy }\end{array}$ & Yes & Yes & Yes & No & No & Yes \\
\hline
\end{tabular}




\section{FIGURES}

\section{Figure 1: Pedigree}

Figure 2: Clinical observations of IV-1 over a 10-day period during a prolonged hospital admission demonstrating periods of hypothermia and bradycardia 


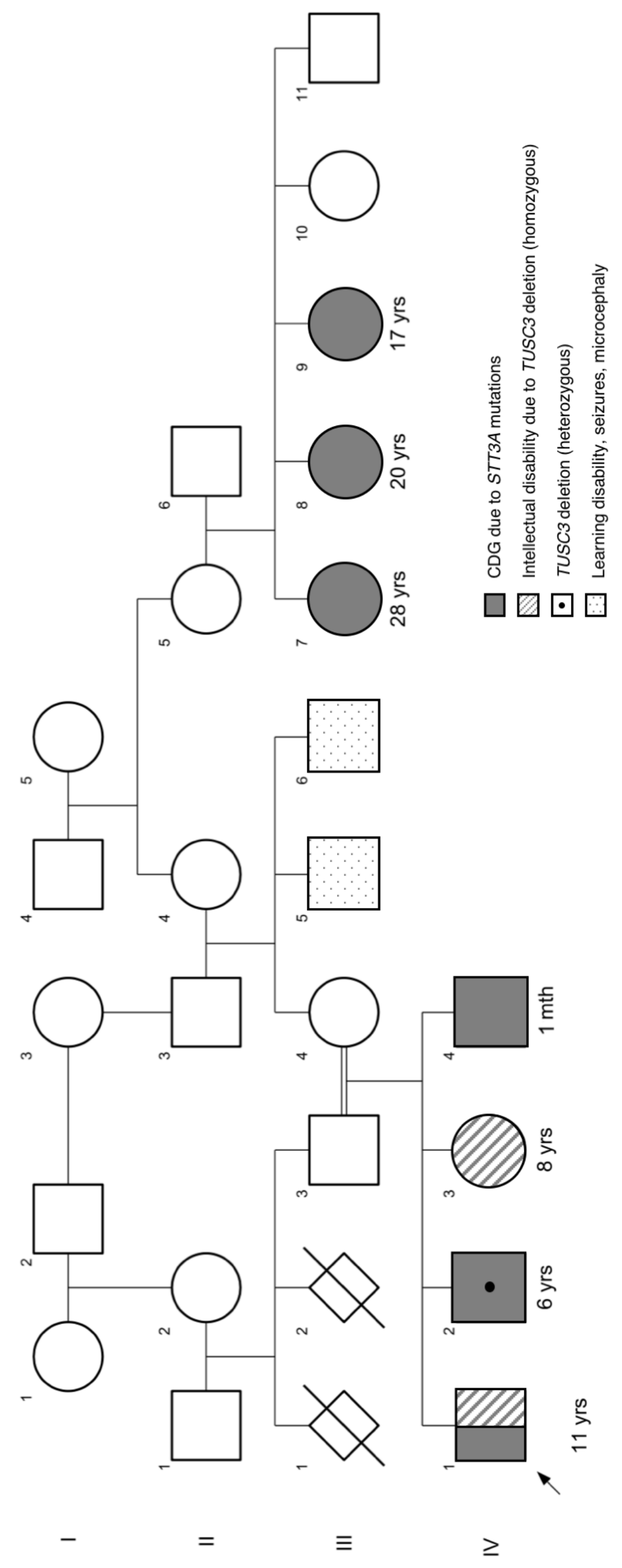




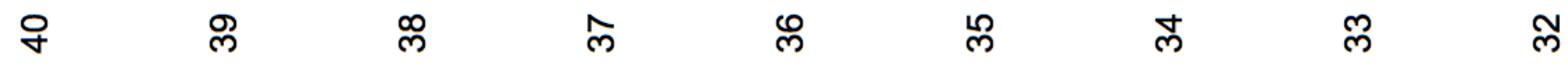

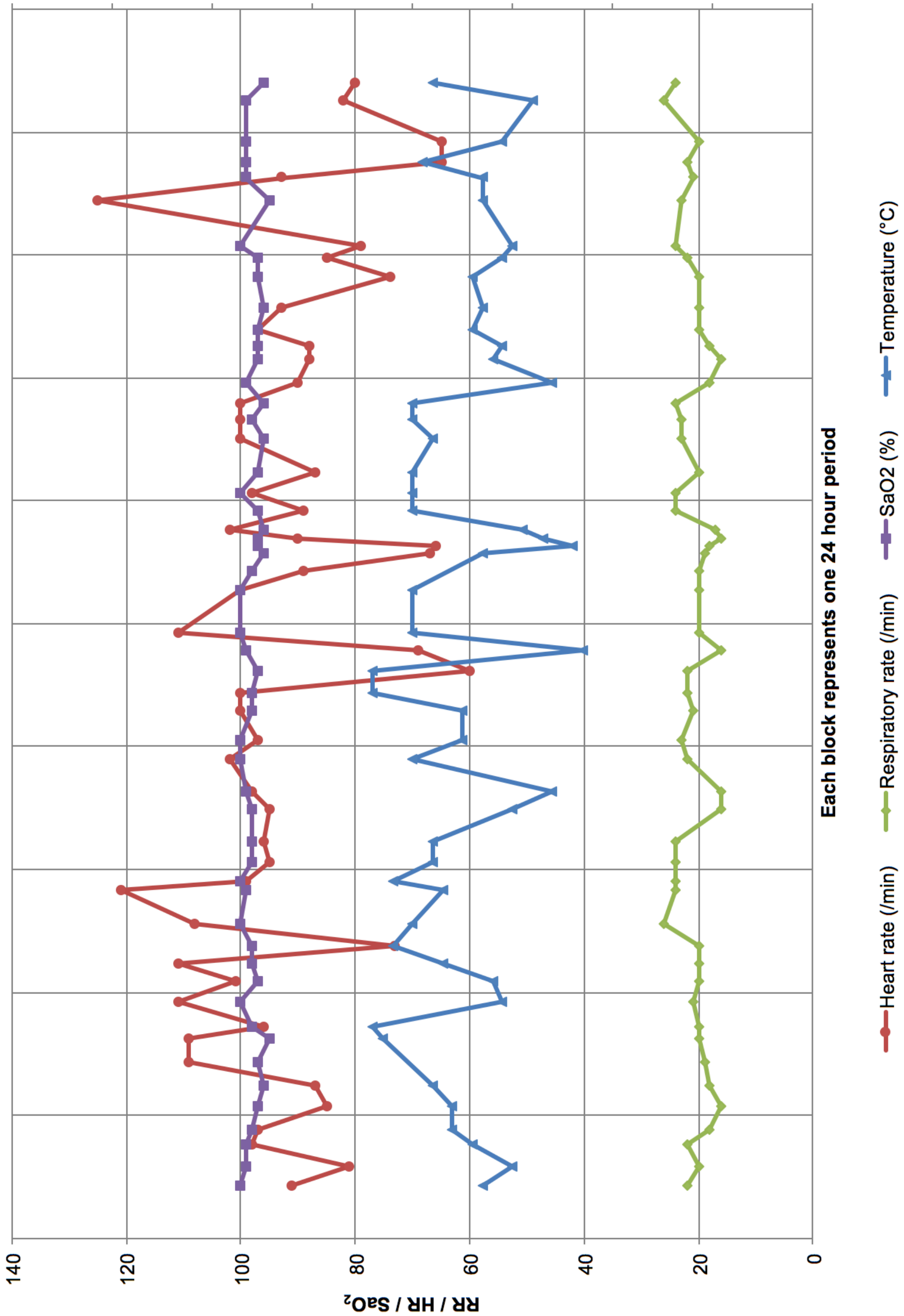




\section{Acknowledgements}

We acknowledge Jackie Till and Guy Besley of the Willink Biochemical Genetics Unit, Manchester and members of the Neuroimmunology laboratory, Queen Square, London, for performing and providing data on transferrin isoelectric focussing.

\section{Declarations of conflict of Interest}

Arunabha Ghosh declares travel assistance from Shire Plc, Biomarin Pharmaceutical, unrelated to the submitted work. Jill Urquhart, Sarah Daly, Diana Scotcher, Andrew Morris and Jill Clayton-Smith have no conflicts of interest to declare.

\section{Patient consent}

All procedures followed were in accordance with the ethical standards of the responsible committee on human experimentation (institutional and national) and with the Helsinki Declaration of 1975, as revised in 2000. Informed consent was obtained from the families of all individuals for being included in the study.

\section{Details of contributions of individual authors}

Arunabha Ghosh reviewed case histories and wrote the manuscript. Jill Urquhart and Sarah Daly performed autozygosity mapping, exome sequencing and Sanger sequencing, and reviewed and edited the manuscript. Diana Scotcher and Anne Ferguson provided clinical information and reviewed the manuscript. Andrew Morris provided clinical information, reviewed and edited the manuscript. Jill Clayton-Smith provided clinical information, reviewed and edited the manuscript. All authors have read and approved the final version of the manuscript. 


\section{References}

1. Cylwik B, Naklicki M, Chrostek L and Gruszewska E. Congenital disorders of glycosylation. Part I. Defects of protein N-glycosylation. Acta biochimica Polonica. 2013; 60: 151-61.

2. $\quad$ Shrimal S, Ng BG, Losfeld ME, Gilmore R and Freeze HH. Mutations in STT3A and STT3B cause two congenital disorders of glycosylation. Human molecular genetics. 2013; 22: 4638-45.

3. Shrimal S and Gilmore R. Reduced expression of the oligosaccharyltransferase exacerbates protein hypoglycosylation in cells lacking the fully assembled oligosaccharide donor. Glycobiology. 2015; 25: 774-83.

4. Ruiz-Canada C, Kelleher DJ and Gilmore R. Cotranslational and posttranslational N-glycosylation of polypeptides by distinct mammalian OST isoforms. Cell. 2009; 136: 272-83.

5. Nilsson I, Kelleher DJ, Miao Y, et al. Photocross-linking of nascent chains to the STT3 subunit of the oligosaccharyltransferase complex. The Journal of Cell Biology. 2003; 161: 715-25.

6. Lefeber DJ, Morava E and Jaeken J. How to find and diagnose a CDG due to defective N-glycosylation. J Inherit Metab Dis. 2011; 34: 849-52.

7. Carr IM, Flintoff KJ, Taylor GR, Markham AF and Bonthron DT. Interactive visual analysis of SNP data for rapid autozygosity mapping in consanguineous families. Human mutation. 2006; 27: 1041-6.

8. Leroy JG. Congenital Disorders of N-Glycosylation Including Diseases Associated With O- as Well as N-Glycosylation Defects. Pediatr Res. 2006; 60: 64356.

9. Ruiz C, Gener B, Garaizar C and Prats JM. Episodic spontaneous hypothermia: a periodic childhood syndrome. Pediatr Neurol. 2003; 28: 304-6.

10. Capanna R, Marcovecchio ML, Verrotti A, Trotta D, Chiarelli F and Mohn A. Episodic spontaneous hypothermia potentially triggered by hyperinsulinemia. Hormone research. 2009; 72: 124-8.

11. Garshasbi M, Hadavi V, Habibi H, et al. A defect in the TUSC3 gene is associated with autosomal recessive mental retardation. American journal of human genetics. 2008; 82: 1158-64.

12. Mohorko E, Glockshuber R and Aebi M. Oligosaccharyltransferase: the central enzyme of N-linked protein glycosylation. J Inherit Metab Dis. 2011; 34: 86978 .

13. Deciphering Developmental Disorders Study. Large-scale discovery of novel genetic causes of developmental disorders. Nature. 2015; 519: 223-8. 